\title{
NOTES
}

\section{NEW ENTRANCE TO THE "NO MAN'S LAND": STATE INJUNCTION OF UNFAIR LABOR PRACTICES AS TORTS FOLLOWING NLRB DECLINATION OF JURISDICTION *}

Tre Taft-Hartley Act ${ }^{1}$ gives the National Labor Relations Board power to assume exclusive jurisdiction over the prevention of unfair labor practices ${ }^{2}$ in interstate commerce. ${ }^{3}$ This power was held in Garner $v$. Teamsters Union, $A F L$, to preclude state injunction of unfair labor practices in industries over which the Board has chosen to exercise its jurisdiction. On the other hand, where the unfair labor practice occurs in a "fringe area" industry which might be in interstate commerce but which the Board has traditionally characterized as local, state injunctive power has not been questioned.5 An area of uncertainty is presented, however, when the Board has assumed jurisdiction over a particular industry, but has subsequently announced that mainly because of budgetary limitations it will decline jurisdiction over all enterprises within that industry transacting less than a prescribed dollar amount of inter-

*Your Food Stores v. Retail Clerks, AFL, 124 F. Supp. 697 (D.N.M. 1954), rev'd an other grounds, LAB. REL. REP. (36 L.R.R.M. 2571) (10th Cir. Aug. 4, 1955).

1. Labor Management Relations Act of 1947, 61 Stat. 136, 29 U.S.C. \& 141 (1952).

2. As enumerated in $\$ 8$ of the LMRA. 61 STAT. 140 (1947), 29 U.S.C. $\$ 158$ (1952).

3. Weber v. Anheuser-Busch, Inc., 348 U.S. 468 (1955); Building Trades Council v. Kinard Constr. Co., 346 U.S. 933 (1954) ; Garner v. Teamsters Union, AFL, 346 U.S. 485 (1953) ; Plankington Packing Co. v. Wisconsin Bd., 338 U.S. 953 (1950) ; Roumell \& Schlesinger, The Preemption Dilemma in Labor Relations, 18 U. DET. L.J. 17, 31-32 (1954); Witney, NLRB Jurisdictional Policies and the Federal-State Relationship, 6 LAB. L.J. 3, 74-75 (1955).

A federal court may enjoin an unfair labor practice only upon complaint filed by the NLRB. Amalgamated Ass'n of Street, Elec. Ry. Employees v. Dixie Motor Coach Corp., 170 F.2d 902 (8th Cir. 1948); Amazon Cotton Mill Co. v. Textile Workers Union, 167 F.2d 183, 188-90 (4th Cir. 1948); International Longshoremen's Union, CIO v. Sunset Line and Twine Co., 77 F. Supp. 119 (N.D. Cal. 1948).

4. 346 U.S. 485 (1953).

5. Hotels are the main example of a "fringe area" industry. The NLRB has never held this industry to be within the scope of the LMRA. Hotel Ass'n of St. Louis, 92 N.L.R.B. 1388 (1951). And state regulation of labor relations in the hotel industry has never been upset. Building Trades Council v. Bonito, 280 P.2d 295, 296 (Nev. 1955). See also Hotel Olds v. State Mediation Bd., 333 Mich. 382, 53 N.W.2d 302 (1952) ; Corn v. Childers, 34 L.R.R.M. 2501 (Ohio Ct. Com. Pleas 1954) ; Hotel Taft, Inc., LAB. ReI. Rep. (35 L.R.R.M. 1593) (Conn. Lab. Bd. Feb. 18, 1955); Bellevue-Stratford Hotel Corp., 33 L.R.R.M. 1009 (Pa. Lab. Bd. Oct. 19, 1953). In Building Trades Council v. Bonito, supra, the Nevada Supreme Court said: "Accepting as the intent of Congress the interpretation of the NLRB itself, the dispute with which we are here concerned falls within a field which the federal government has declined to occupy." 
state business. ${ }^{b}$ As used by the Board, declination of jurisdiction means a refusal to hear certain disputes, not a determination that such disputes are beyond the scope of the act. ${ }^{7}$ The Supreme Court has specifically left open the question of the validity of state injunction of unfair labor practices occur-

6. For jurisdictional standards currently in effect, see NLRB Announces Changes in Standards For Its Exercise of Jurisdiction, NLRB Press Release, No. 445, July 1, 1954; NLRB Announces New Standards For Exercise of Jurisdiction, NLRB Press Release, No. 449, July 15, 1954. Complaints falling outside these standards are regularly dismissed. E.g., Breeding Transfer Co., 110 N.L.R.B. No. 64 (Oct. 28, 1954); Jonesboro Grain Drying Cooperative, 110 N.L.R.B. No. 67 (Oct. 28, 1954); Hogue and Knott Super Markets, 110 N.L.R.B. No. 68 (Oct. 28, 1954).

The reasons for formulation of the monetary jurisdictional standards were listed in Breeding Transfer Co., supra, at p. 7: "(1) the problem of bringing the case load of the Board down to manageable size, (2) the desirability of reducing an extraordinarily large case load in order that we might give adequate attention to more important cases, (3) the relative importance to the National economy of essentially local enterprises as against those having a truly substantial impact on our economy, and (4) over-all budgetary policies and limitations." See also Federal Dairy Co., 91 N.L.R.B. 638, 639 (1950); NLRB brief in Haleston Drug Stores, Inc. v. NLRB, 187 F.2d 418, 421 (9th Cir. 1951) as quoted in Feldblum, Jurisdictional "Tidelands" in Labor Relations, 3 LAB. L.J. 114, 115 (1952) : "Because both case-load and budget vary from time to time . . . cases which, at one period, warrant an assertion of jurisdiction may not warrant it at another period, and vice versa."

NLRB declination of jurisdiction was generally met with judicial approval. Local 12, Progressive Mine Workers v. NLRB, 189 F.2d 1 (7th Cir.), cert. denied, 342 U.S. S6S (1951) ; Haleston Drug Stores, Inc. v. NLRB, 187 F.2d 418, 421 (9th Cir.), cert. denied, 342 U.S. 815 (1951). But see Joliet Contractors Ass'n v. NLRB, 193 F.2d 833 (7th Cir. 1952) (declination of jurisdiction held abuse of discretion), criticized in Note, 62 YALE L.J. 116 (1952). In NLRB v. Denver Building Council, 341 U.S. 675, 684 (1951), the Supreme Court passively approved the NLRB's discretionary power to decline jurisdiction:

"Even when the effect of activities on interstate commerce is sufficient to enable the Board to take jurisdiction of a complaint, the Board sometimes properly declines to do so, stating that the policies of the Act would not be effectuated by its assertion of jurisdiction in that case."

7. In declining jurisdiction over a dairy company the Board said:

"In the past, we have concluded that, in cases of this kind, an interruption of such inflow by a labor dispute-though the volume of out-of-State purchases be substantial-would not be likely to have a sufficient impact upon interstate commerce to justify an already burdened Federal Board in expending time, energy, and public funds. In the light of more than 3 years' experience under the amended Act and the Board's current budget and case load, we now conclude that, although it would effectuate the policies of the statute to assert jurisdiction in cases of this kind where the direct inflow is substantial, due regard for these factors requires that we continue to decline jurisdiction where the direct inflow is less than $\$ 500,000$ in value annually."

Federal Dairy Co., 91 N.L.R.B. 638, 639 (1950).

Instances where the Board declines jurisdiction because of case load and budgetary limitations must be distinguished from cases where the Board declines to take action after considering the merits of the case. In Bethlehem Steel Co. v. New York State Labor Relations Bd., 330 U.S. 767, 775 (1947), the Court held that where the Board evidences a positive policy of not certifying foremen's unions, state certification in conflict with this policy is precluded. 
ring in businesses which fall below the Board's limits. ${ }^{8}$ If states cannot enjoin in this area, a "no man's land" results where both employers and employees are denied an effective remedy against conduct which may be violative of both state and federal law. ${ }^{9}$

Section $10(a)^{10}$ of the act appears to foreclose the possibility of states' preventing unfair labor practices in the "no man's land" with injunctions based on state labor laws. ${ }^{11}$ This statute authorizes the Board to cede jurisdiction by agreement to those states which have labor laws "consistent" with the Federal act. Of the twelve states that have comprehensive labor relations laws, ${ }^{12}$ none has apparently met the consistency requirement. ${ }^{13}$ This provision would seem to establish the sole conditions under which Congress intended state labor laws to operate in those industries over which the Board has asserted its jurisdiction. ${ }^{14}$ While there is opposing authority, ${ }^{15}$ the argument that

8. Building Trades Council v. Kinard Constr. Co., 346 U.S. 933 (1954); Garner v. Teamsters Union, AFL, 346 U.S. 485, 488 (1953) ; Bethlehem Steel Co. v. New York State Labor Relations Bd., 330 U.S. 767, 776 (1947).

9. See Brody, Federal Pre-Emption Comes of Age in Labor Relations, 5 LAB. L.J. 743 (1954); Feldblum, Jurisdictional "Tidelands" in Labor Relations, 3 LAB. L.J. 114 (1952); Schwartz, Local Business-No Man's Land in Labor Relations, 1 LAB. L.J. 189 (1949); Witney, NLRB Jurisdictional Policies and the Federal-State Relationship, 6 LAB. L.J. 3 (1955).

Recent decisions have approved state regulation in the "no man's land." Your Food Stores v. Retail Clerks, AFL, 124 F. Supp. 697 (D.N.M. 1954) ; Satin, Inc. v. Electrical Workers, 34 L.R.R.RI. 2258 (Mich. Cir. Ct. 1954); Victory Chain, Inc., 34 L.R.R.M. 1664 (N.Y. Lab. Bd. Sept. 29, 1954) ; Cooper-Utter Lumber Co., 34 L.R.R.M. 1287 (Wis. Bd. 1954). Cf. Benjamin v. Foidl, 379 Pa. 540, 109 A.2d 300 (1954) (no finding that relief was not available from the NLRB). Contra, Universal Car Co. v. International Ass'n of Machinists, AFL, LAB. Ret. Rep. (35 L.R.R.M. 2087) (Mich. Cir. Ct. Nov. 1, 1954) ; cf. New York Labor Bd. v. Wags Transp. System, Inc., 130 N.Y.S.2d 731 (Sup. Ct.), aff'd, 284 App. Div. 883, 134 N.Y.S.2d 603 (1st Dep't 1954).

10. 61 STAT. 146 (1947), 29 U.S.C. \$ 160(a) (1952).

11. Universal Car Co. v. International Ass'n of Machinists, AFL, LAB. REL. REP. (35 L.R.R.M. 2087) (Mich. Cir. Ct. Nov. 1, 1954); New York Labor Bd. v. Wags Transp. System, Inc., 130 N.Y.S.2d 731 (Sup. Ct.), aff'd, 284 App. Div. 883, 134 N.Y.S. 2d 603 (1st Dep't 1954). See Brody, supra note 9, at 763-64; Schwartz, supra note 9, at 196-97; Witney, supra note 9, at 75-80.

12. Colo. Rev. Stat. c. 80, art. 4, 5 (1953) ; Conn. Gen. Stat. \$\$ 7388-99 (1949), as amended, (Supp. 1953) ; KAN. GEN. Stat. $\$ \$ 44-601$ to $44-660$ (1949); Mass. ANN. Laws c. $150 \mathrm{~A}$, $\$ \$ 1-12$, as amended, (Supp. 1954); Mrсн. Stat. ANv. $\$ 17.454$, as amended, (Supp. 1953) ; Minv. Stat. ANN. $\S 179$, as amended, (Supp. 1954) ; N.Y. Lab. ReL. Act §§ 700-16; Obe. Rev. Stat. \$\$.661.010-662.790 (1953); PA. Stat. Anw. tit. 43, $\$ \S 211.1-13$ (1952) ; R.I. Acts and Resolves 1941, c. 1066, as amended, 1942 c. 1247 , 1947 c. 1946, 1948 c. 2014, 2016; UTAr CODE ANN. \$§ 34-1-1 to 34-1-34, as amended, (Supp. 1955); WIs. STat. $\$ \S 111.01-19$ (1953).

13. See Breeding Transfer Co., 110 N.L.R.B. No. 64, p. 41 (Oct. 28, 1954) (dissenting opinion); Brody, supra note 9, at 764; Feldblum, supra note 9, at 116-17; S. REP. No. 986, 80th Cong., 2nd Sess. 30 (1948).

14. While $\S 10$ (a) now operates as a restriction on cession, it was adopted to make certain the Board's power to cede. Until the Supreme Court's decision in Bethlehem Steel Co: v. New York Labor Bd., 330 U.S. 767 (1947), the power of the NLRB to 
NLRB declination of jurisdiction is not a cession agreement within the meaning of section 10 (a) appears eminently sound..$^{16}$ Moreover, Congress recently lent support to this position by failing to pass a bill designed to repeal section 10 (a)'s limitations and to allow the states to act whenever the Board declined jurisdiction. ${ }^{17}$

make cession agreements with state boards was not questioned. See Agreement between the New York Labor Bd. and the NLRB, reprinted as an appendix to the concurring opinion of Justice Frankfurter. Id. at 784-97; Brody, supra note 8, at 747. The effect of Bethlchem was to leave the Board's cession power in doubt. Id. at 778 (concurring opinion of Justice Frankfurter). In the Taft-Hartley Act, Congress intended to resolve this doubt by including a specific cession provision in $\$ 10(\mathrm{a})$. The new measure authorized the Board to cede jurisdiction in any industry to state and territorial agencies subject to two conditions:

"(a) That it can cede jurisdiction in cases arising in mining, manufacturing, communications, and transportation only when the employer's operations are predominantly local in character, and (b) that it may cede jurisdiction only if the applicable provisions of the State or Territorial statute and the rules of decision thereunder are consistent with the corresponding provisions of the National Act, as interpreted and applied by the Board and by the Courts."

H.R. Rep. No. 510, S0th Cong., 1st Sess. 52 (1947).

The restrictions of $\$ 10(\mathrm{a})$, however, do not seem to preclude a state from applying its body of non-labor law to remedy wrongs resulting from a labor dispute so long as the state remedy does not conflict with federal remedies available under the LMRA. See text at note 26 infra. Congress intended the $\$ 10$ (a) conditions to apply only to application of state labor laws.

"The Board is now receiving a tremendous volume of cases. The desirability of permitting it to reduce this load of cases by ceding jurisdiction over borderline industry, businesses primarily local in nature whose operations only indirectly affect interstate commerce, appears obvious. However, if it can only be done by an amendment to the act which would permit inconsistent regulations and as many different policies as there are States having labor relations acts, the desirability appears questionable."

S. REP. No. 9\&6, S0th Cong., 2d Sess. 31 (1948) (emphasis added).

15. Satin, Inc. v. Electrical Workers, 34 L.R.R.M. 2258 (Mich. Cir. Ct. May 12, 1954); Victory Chain, Inc., 34 L.R.R.M. 1664 (N.Y. Lab. Bd. Sept. 29, 1954); Cooper-Utter Lumber Co., 34 L.R.R.M. 1287 (Wis. Bd. May 24, 1954).

16. See Brody, supra note 9, at 764; Witney, supra note 9, at 75-80.

Application of state labor laws to "fringe area" industries, however, is probably not precluded by $\$ 10$ (a) since the NLRB has never established that such industries fall within the scope of the federal act. See text at notes 5, 6 supra. Although Congress phrased the law in terms of the broadest exercise of the commerce power, NLRB v. Fainblatt, 306 U.S. 601, 607 (1939), the act's exact coverage was never defined; it was left to the NLRB's discretion. Haleston Drug Stores, Inc. v. NLRB, 187 F.2d 418, 421 (9th $\mathrm{Cir}$ ), cert. denicd, 342 U.S. 815 (1951). The cession restriction of $\S 10$ (a) applies to the "no man's land," however, because this area develops only where the NLRB declines jurisdiction over an enterprise previously determined to be within the scope of the act.

17. S. 1264, introduced by Senator Ives in the 1st Session of the 83d Congress, provided: “. . .

"(2) Nothing contained in this act shall be deemed to prevent or bar any agency, or the courts, of any State or Territory, from assuming and asserting 
In the recent case of Your Food Stores v. Retail Clerks, AFL, ${ }^{18}$ a United States district court for the first time explored the possibility of allowing states to remedy unfair labor practices in the "no man's land" by issuing injunctions grounded on tort law. The district court, in refusing to enjoin a state court proceeding, upheld the jurisdiction of the state court to enjoin picketing where the union's conduct was a common law trespass. ${ }^{19}$ The allegation of trespass was based on the fact that the picketing was being conducted on a company-owned sidewalk. ${ }^{20}$ In a prior suit in the state court, the employer had sought to enjoin the same picketing, alleging that it constituted a section 8 unfair labor practice. The first action was removed to the district court and dismissed on the grounds that the controversy was within the NLRB's exclusive jurisdiction. ${ }^{21}$ Subsequent to the first suit, the Board altered its jurisdictional standards to exclude this controversy. In the instant case the federal court stated that the change in the NLRB's standards was tantamount to an intervening change in the law which would prevent the first suit from acting as a bar. ${ }^{22}$

jurisdiction over labor disputes over which the Board declines... to assert jurisdiction."

99 ConG. Rec. 1846-48 (1953). A similar provision was contained in the proposed general revision of the LMRA which Congress failed to pass last year. S. REP. NNo. 1217, 83d Cong., $2 \mathrm{~d}$ Sess. 28 (1954). For other proposed amendments to $\$ 10(\mathrm{a})$, see Harris, A CIO Vieze, 43 GEo. L.J. 344, 357-58 (1955) ; Roumell \& Schlesinger, The Precmption Dilemma in Labor Relations, 18 U. DET. L.J. 135, 135-70 (1955).

18. 124 F. Supp. 697 (D.N.M. 1954).

19. Id. at 701-03.

20. Id. at 700 .

21. Your Food Stores v. Retail Clerks, AFL, 121 F. Supp. 399 (D.N.M. 1954). Jurisdiction was presumably based upon 28 U.S.C. $\$ 1337$ (1952) which gives federal district courts original jurisdiction over a proceeding arising under an act of Congress regulating commerce. The district court's opinion did not state which provisions of the LMRA had been violated, but the Food Stores complaint alleged that the picketing violated $\$ \S 8(\mathrm{a})(1), 8(\mathrm{~b})(2)$. Brief for Appellants, p. 4, Retail Clerks, AFL v. Your Food Stores, -F.2d-(10th Cir. 1955) [hereinafter cited as Brief for Appellants]. Apparently the applicable provision was $\S 8(\mathrm{~b})$ (2) which makes it an unfair labor practice for a union to attempt to cause an employer to discriminate against his employees by encouraging membership in a union which has not been selected as the bargaining representative by a majority of the employees. The complaint alleged that the union was picketing to coerce the employer into agreeing to a union shop after the union had refused the employer's offer to hold a representation election.

22. Your Food Stores v. Retail Clerks, AFL, 124 F. Supp. 697, 703 (D.N.M. 1954). The second action commenced as a suit for an injunction in a county court of New Mexico. The defendant union applied to the federal district court to have the state action enjoined under 28 U.S.C. $\$ 2283$ (1952) which permits a federal court to enjoin a state court proceeding only "where necessary in aid of its jurisdiction or to protect or effectuate its judgments."

The district court's refusal to enjoin the state court action was reversed by the Tenth Circuit on grounds of res judicata. Retail Clerks v. Your Food Stores, LAB. REL. REP. (36 
The result in Your Food Stores seems based on little more than a desire to supply a remedy to a party already denied opportunity to seek relief from the NLRB. The federal court argued that since trespass is not an enumerated unfair labor practice, it may be enjoined by a state court. ${ }^{23}$ But this conclusion begs the key question of whether a state in a "no man's land" situation can enjoin conduct which is both a tort under state law and an unfair labor practice under federal law. When the court finally faced this question, it based an affirmative answer solely on the ground that the alternative to allowing state injunctions would be a "legal vacuum" in which the employer would be denied relief before both federal and state tribunals. Citing evidence of judicial disapproval of such situations, the court upheld the state injunction. ${ }^{24}$

A more persuasive justification for the result in Your Food Stores can be developed from Supreme Court decisions construing the role of state regulation in labor relations. The Court has made it clear that Congress did not intend to deprive the states of regulatory power over all conduct resulting from labor disputes in interstate commerce. ${ }^{25}$ State power appears to be un-

L.R.R.M. 2571) (10th Cir. Aug. 4, 1955). The Tenth Circuit held that in the first district court decision, see note 21 supra, the claims for an injunction to prevent an unfair labor practice and to prevent a tort were both presented and rejected. It held further that the NLRB's declination of jurisdiction "did not of itself alter the pertinent law thereby revesting the state caurt with authority to proceed." The opinion properly cited $\$ 10$ (a) to show that no authority had been "revested." But the court then either assumed that the negative implication of 10 (a) precludes state tort law or it did not consider the question. In any event, the argument that state tort law is not governed by 10 (a), see note 16 supra, and the argument that state tort law is therefore available in the "no man's land" even if state labor law is barred, see text at notes 25-37 infra, were not made to the court nor explicitly ruled on.

23. Your Food Stores v. Retail Clerks, AFL, 124 F. Supp. 697, 701-03 (D.N.M. 1954).

24. Id. at 702-03. The court cited Allen-Bradley v. Wisconsin Bd., 315 U.S. 740 (1942) and International Union, UAWA, AFL v. Wisconsin Bd., 336 U.S. 245, 254 (1948) (the Briggs-Stratton case) to support the proposition that a "situation which creates an apparent legal vacuum is not one which appeals to a Court." But in neither of these two cases, where state injunctions were upheld, was the conduct enjoined an unfair labor practice.

25. Allen-Bradley v. Wisconsin Bd., supra note 24 , upheld a state injunction of violence and mass picketing. Even if the picketing in which the violence occurs constiutes a $\$ \&$ unfair labor practice, states still have the power to enjoin its violent aspects. Irving Subway Grating Co. v. Silverman, 117 F. Supp. 671 (E.D.N.Y. 1953); Wilkes Sportswear, Inc. v. International Ladies' Garment Workers' Union, 110 A.2d 418, 420 (Pa. 1955) ; Wisconsin Bd. v. United Automobile Workers, 70 N.W.2d 191, 269 Wis. 578 (1955). See also Perez v. Trifiletti, 74 So. $2 d 100$ (Fla. 1954), cert. denied, 348 U.S. 926 (1955) (all picketing enjoined upon proof of some violence).

In the Briggs-Stratton case, supra note 24, the Supreme Court upheld a state injunction of intermittent work stoppages, conduct which is neither a $\$ 8$ unfair labor practice nor protcted concerted activity under $\$ 7$. For a recent application of the Briggs-Stratton doctrine, see Miliwaukee Boston Store Co. v. Hosiery Workers, AFL, 69 N.W.2d 762, 269 
impaired unless its exercise contravenes an express provision of the federal law or parallels a remedy which Congres intended to be exclusive. Undoubtedly state prohibition of activity explicitly protected by section 7 must fall. ${ }^{20}$ Furthermore, the Supreme Court has established that remedies available before the NLRB were intended to be exclusive. In Garner, the Court barred exercise of a state's labor law where it was not shown that the NLRB would decline jurisdiction. ${ }^{27}$ Similarly, in Weber v. Anheuser-Busch, Inc., ${ }^{28}$ the Court struck down an injunction based on a state's anti-trust law where it appeared that the Board might remedy the enjoined conduct. ${ }^{29}$ But where the Board has withdrawn its remedial procedures from a designated area, by basing jurisdiction on monetary standards, state prevention of unfair labor practices neither clashes with federal law nor parallels federal remedies. ${ }^{30}$

Wis. 338 (1955). This case involved the power of Wisconsin to enjoin a secondary boycott maintained by a union against a neutral employer. Section 8(b) (4), the secondary boycott provision of the LMRA, did not apply since it prohibited such boycotts only when they involved coercion of the neutral employer's employees. The court therefore held that since such boycotts were neither a protected activity under $\$ 7$ nor a prohibited activity under $\$ 8$, the state injunction would stand. See also Truck Drivers v. Whitfield Transp., Inc., 273 S.W.2d 857, 860 (Tex. 1954) where the Texas Supreme Court held that, although the facts of the case did not warrant an injunction, the state had jurisdiction to enjoin a secondary boycott being carried on by interstate truckers as a result of alleged union coercion; this activity was neither protected nor prohibited by the LMRA.

26. International Union of United Automobile Workers, CIO v. O'Brien, 339 U.S. 454, 459 (1950); Amalgamated Ass'n of Street Elec. Ry. Workers v. Wisconsin Bd., 340 U.S. 383, 389-93 (1951) ; Hill v. Florida $c x$ rcl. Watson, 325 U.S. 538, 544 (1945) (concurring opinion).

27. Garner v. Teamsters Union, AFL, 346 U.S. 485, 488 (1953).

28. 348 U.S. 468 (1955).

29. Id. at 477-79. The complaint, filed-in the state court, in addition to alleging a violation of state law also claimed that the picketing was an unfair labor practice under $\$ \S 8$ (b) (4) (A), (B), (D) of the LMRA. Prior to the decision of the Missouri Supreme Court, the NLRB had ruled that there was no unfair labor practice under $\$ 8(b)$ (4) (A). However, the United States Supreme Court held that since the Board had not made a positive finding that $\S 8$ (b) (4) (B), (D) had not been violated, the state court lacked jurisdiction.

30. See Feldblum, Jurisdictional "Tidelands" in Labor Relations, 3 LAB. L.J. 114, 119-20 (1952). Cf. Rice v. Santa Fe Elevator Corp., 331 U.S. 218 (1947); Southern Pac. Co. v. Arizona, 325 U.S. 761 (1945). In Rice the question arose as to whether an Illinois law regulating security issues of warehouses and other public utilities conflicted with the United States Warehouse Act. 39 Stat. 486 (1916), as amended, 7 U.S.C. $\$ \S 241-73$ (1952). In holding that Illinois could exert regulation which might conflict with powers which the Secretary of Agriculture possessed but which he had not yet exercised, the Court said: "[W]e are told that the Secretary of Agriculture has made no attempt to exercise jurisdiction. ... Possibilities of conflict and repugnancy are conjured up. . . . But it will be time to consider such asserted conflicts between the State and Federal Acts when and if they arise. Any such objections are at this stage premature." Rice v. Santa Fe Elevator Corp., supra at 237. In Southern Pacific the question was whether state regulation of train lengths conflicted with $\S 1$ of the I.C.C. Act, 24 STAT. 379 (18S7), 
The Court's willingness to tolerate state regulation absent conflict of law or procedure was demonstrated in United Construction Workers v. Laburmum Construction Co. ${ }^{31}$ The Court there affirmed a state's right to award damages for conduct which constituted both a tort and an unfair labor practice. The Court reached this result by developing from Garner the following rule: "To the extent that Congress prescribed preventive procedure against unfair labor practices, that case recognized that the Act excluded conflicting state procedure to the same end." 32 But where as in Weber the state court sought to enjoin conduct which constituted an unfair labor practice, the availability of this remedy from the NLRB barred the state action. ${ }^{33}$ Thus, where the Board is exercising its jurisdiction, absence of conflicting remedy is the test for state regulation. That this test applies outside the Board's self-imposed limits is evidenced by the extensive activity of state labor boards in the "fringe area" industries. ${ }^{34}$ Even though the Board could extend its jurisdiction to the limits of the commerce power and thereby provide remedies for "fringe area" disputes, ${ }^{35}$ this dormant power has never been held to bar state regulation. ${ }^{36}$ It thus appears that states may properly enjoin unfair labor practices in the "no man's land"- -an area where the state remedy is not "a conflicting state procedure."37

49 U.S.C. $\$ 1$ (1952), authorizing the Interstate Commerce Commission to regulate car scrvice in an emergency. In hoiding that state regulation was valid the Court said: "we are of the opinion that, in the absence of administrative implementation by the Commission, $\$ 1$ does not of itself curtail state power to regulate train lengths." Southern Pac. Co. v. Arizona, supra at 764-65. See also Northwestern Bell Tel. Co. v. Nebraska Ry. Comm'n, 297 U.S. 471,478 (1936) ; Welch Co. v. New Hampshire, 306 U.S. 79, 84 (1939) (state regulation pending action by a federal administrative agency upheld).

There is no likelihood of conflict even if the Board should in the future alter its monetary standards to include enterprises over which it now declines to exercise jurisdiction. When faced with this situation in the past, the Board has declined to issue a complaint based on an unfair practice occurring at a time when the Board was not exercising jurisdiction over the parties involved. Braukman, d.b.a. Screw Machine Products Co., 94 N.L.R.B. 1609 (1951); Yellow Cab Co., 93 N.L.R.B. 766 (1951).

31. 347 U.S. 656 (1954).

32. United Constr. Workers v. Laburnum Constr. Co., 347 U.S. 656, 665 (1954). The tort in Laburnum was the causing of a stoppage of work by threats of violence. But the opinion addressed itself to the availability of a state remedy for any common law tort which is also an unfair labor practice. Id. at 657. See Brody, Federal Pre-Emption Comes of Agc in Labor Relations, 5 LAB. L.J. 743, 758-59 (1954).

33. See note 29 supra and accompanying text.

34. See note 5 supra.

35. Polish Nat'l Alliance v. NLRB, 322 U.S. 643, 647 (1944) ; NLRB v. Fainblatt, 306 U.S. 601 (1939) ; NLRB v. Jones \& Loughlin Streel Corp., 301 U.S. 1, 36-37 (1937). See also United States v. Sullivan, 332 U.S. 689, 697-98 (1947); Wickard v. Filburn, 317 U.S. 111 (1942). In NLRB v. Fainblatt, sutpra at 607, it was said:

"Examining the Act in the light of its purpose and of the circumstances in which it must be applied we can perceive no basis for inferring any intention of Congress to make the operation of the Act depend on any particular volume of commerce affected more than that to which courts would apply the maxim de mimimis."

36. See cases cited at note 5 supra.

37. See text at note 32 supra. 
Application of state tort law to "no man's land" disputes will not provide remedies for all unfair labor practices in this area. While "no man's land" employers will often get relief, "no man's land" employees almost never will."3s It is difficult to see how any of the enumerated employer unfair labor practices can be classified as common law torts. A principal purpose of enacting the Wagner Act ${ }^{39}$ was to create employee rights which did not exist at common law. ${ }^{40}$ Therefore, the "no man's land" employee remains without relief since application of state labor laws per se is precluded by section 10(a)'s restriction on cession. ${ }^{41}$ On the other hand, "no man's land" employers will generally get relief since picketing which violates section 8 almost always causes some disruption in the employer's business with resulting damage to it. ${ }^{42}$

Perhaps justification for this inequity can be derived from the argument that unremedied unfair labor practices may cause more serious damage to the "no man's land" employer than to his employees. While the employee

38. Where state law permits, "no man's land" employees working under collective bargaining agreements presumably do have a remedy in contract for employer unfair labor practices which breach such agreements. Compare Dufour v. Continental So. Lines, Inc., 219 Miss. 296, 68 So. 2d 489 (1953) (contract action allowed), with Swart v. Huston, 154 Kan. 182, 117 P.2d 576 (1941). More often state law permits the union to recover for breach of a collective bargaining agreement. See Note, 63 Y ALE L.J. 1173, 1173-79 (1954). In some instances unions have obtained specific performance. See Note, 39 CoRnell L.Q. 344 (1954). Under $\$ 301$ of the LMRA, 61 STAT. 156 (1947), 29 U.S.C. $\S 185$ (1952), a union may sue in the federal courts to enforce collective bargaining agreements regardless of diversity or jurisdictional amount. See Note, 63 YaLE L.J. 1173,1175 (1954). The Supreme Court has recently held that a union may not sue under $\S 301$ on behalf of individual employees to enforce rights to wages. Association of Westinghouse Salaried Employees v. Westinghouse Elec. Corp., 348 U.S. 437 (1955). However, the Court did not completely invalidate $\$ 301$; it is possible that a union may still be able to sue under this provision on its own behalf. Westinghouse apnears to assume that $\$ 301$ does not preclude application of state laws in the enforcement of collective bargaining agreements. Id. at 459 . In the lower courts, the weight of authority holds that $\$ 301$ does not preempt the field. Note, 63 YALE L.J. 1173, 1180 n.27 (1954).

But absent the protection of a collective bargaining contract, the "no man's land" employee would appear to have no remedy for discriminatory treatment or discharge by the employer because of union activities. Since in the ordinary individual contract of hire the employee is not bound to work for any specified period of time, it is doubtful if the employer would consent to a clause qualifying his right to terminate the employment at will. And the NLRB's current jurisdictional standards exclude enterprises which "have the lowest incidence of collective bargaining and employee self-organization and ... in which organizational activity by unions is most intense." Breeding Transfer Co., 110 N.L.R.B. No. 64, p. 34 (Oct. 28, 1954) (dissenting opinion). The majority of "no man's land" employees would thus appear to be without a remedy for employer unfair labor practices.

39. National Labor Relations Act, 49 STAт. 449 (1935).

40. See Justice Douglas's dissent in United Constr. Workers v. Laburnum Constr. Co., 347 U.S. 656, 670 (1954). See also Statement of Findings and Policies in the NLRA, 49 StAт. 449 (1935), as amended, 29 U.S.C. \$ 141 (1952).

41. See text at notes 10-17 supra.

42. Your Food Stores v. Retail Clerks, AFL, 124 F. Supp. 697 (D.N.M. 1954)

(trespass); Benjamin v. Foidl, 379 Pa. 540, 109 A.2d 300 (1954) (undefined common 
can move to another job with relative freedom, the employer is saddled with the responsibility of a substantial investment. The loss of income resulting from interruption of his business combined with the burden of recurring fixed costs can quickly drive the small entrepreneur to financial ruin. But does not the loss of income to an employee resulting from an unjust dismissal for union activities present just as serious a problem? A long period may elapse before he can be suitably re-employed, during which time he may suffer severe economic hardship.

Whether states are permitted to grant injunctive relief to a "no man's land" employer, or whether both employer and employee are denied relief, a thoroughly unsatisfactory situation remains. In either event a remedy is denied to a genuinely aggrieved party. Many state courts will probably try to solve this problem by ignoring the restrictions of section 10 (a) and holding that an NLRB declination of jurisdiction operates as a passive cession to the states. ${ }^{43}$ But even within the limitation of section 10(a), Your Food Stores indicates the likelihood of state relief through application of tort law. ${ }^{44}$ If states are going to resolve "no man's land" disputes, they should not be handicapped by a prohibition on the use of labor laws. Section 10 (a) should be amended to permit effective state regulation of labor disputes whenever the Board declines jurisdiction. . $^{45}$ Prior to such amendment the Board should reappraise its jurisdictional standards with a view toward an exercise of its regulatory power sufficient to assure a uniform labor policy in interstate commerce, and Congress through adequate appropriations should guaranty the effectiveness of this power.

law conspiracy); Weber v. Anheuser-Busch, Inc., 364 Mo. 573, 265 S.W.2d 325 (1954), . rev'd, $34 S$ U.S. 468 (1955) (conspiracy in restraint of trade).

43. See cases cited at note 15 supra.

44. See text at notes 1S-37 supra.

45. See Senator Ives' proposed amendment quoted at note 17 supra. 